\title{
EVALUASI PELAYANAN SARANA DAN PRASARANA PROTEKSI KEBAKARAN PADA PERMUKIMAN PERKOTAAN
}

\author{
Evaluation of Fire Protection Facilities and Infrastructure in Urban \\ Residentials
}

\section{Pipin Yunita Sari ${ }^{1}$, Soekmana Soma ${ }^{1}$ and Linda Dwi Rohmadiani ${ }^{2}$}

\begin{abstract}
Abstrak: Kejadian kebakaran di Kota Sidoarjo 5 tahun terakhir semakin meningkat. Penyebab utama kebakaran mayoritas karena aktifitas permukiman dan ilalang. Tujuan penelitian ini adalah mengevaluasi tingkat pelayanan sarana dan prasarana proteksi kebakaran pada permukiman perkotaan Kota Sidoarjo berdasarkan Peraturan Menteri Pekerjaan Umum No.20/PRT/M/2009 tentang Pedoman Teknis Manajemen Proteksi Kebakaran. Wilayah penelitian terdiri atas Kecamatan Sidoarjo, Kecamatan Candi dan Kecamatan Buduran. Pendekatan penelitian yang digunakan adalah penelitian deskriptif evaluatif. Hasil penelitian menunjukkan tingkat pelayanan sarana dan prasarana proteksi kebakaran di Kota Sidoarjo masih 48\%, perlu peningkatan dari aspek kelengkapan bangunan Pos Pemadam Kebakaran, ketersediaan Pos Pemadam Kebakaran dan hidran serta peningkatan partisipasi masyarakat.
\end{abstract}

Keyword: permukiman perkotaan, proteksi kebakaran, sarana dan prasarana

\begin{abstract}
The incidence of fires in the city of Sidoarjo in the last 5 years has increased. The main causes of the majority of fires were settlement activities and weeds. The aim of this study was to evaluate the level of fire protection facilities and infrastructure services in the urban settlements of Sidoarjo City based on Minister of Public Works Regulation No.20 / PRT / M / 2009 concerning Technical Guidelines for Fire Protection Management. The study area consisted of Sidoarjo District, Candi District and Buduran District. The research approach used is descriptive evaluative research. The results showed that the level of fire protection facilities and infrastructure services in the city of Sidoarjo was still $48 \%$, it needed an increase in the aspects of the completeness of the Fire Extinguishers building, the availability of fire stations and hydrants as well as increasing community participation.
\end{abstract}

Keyword:, facilities and infrastructure, fire protection, urban settlement

\section{PENDAHULUAN}

Kota Sidoarjo dengan luas wilayah 48.838,11 Ha (7\% dari luas kabupaten) meliputi 3 kecamatan yaitu Kecamatan Buduran, Kecamatan Sidoarjo dan Kecamatan Candi. Kepadatan penduduk Kota Sidoarjo pada tahun 2010 berdasarkan data BPS sebesar 111 jiwa/Ha kemudian naik sebesar 35\% menjadi 150 jiwa/Ha pada tahun 2017. Semakin meningkatnya kepadatan penduduk di Kota Sidoarjo maka akan ada kecenderungan peningkatan kepadatan bangunan. Semakin tinggi kepadatan bangunan mengakibatkan semakin tinggi potensi terjadinya kebakaran (Andriyanto, 2013). Kota Sidoarjo masuk dalam Sub Satuan Wilayah Pengembangan II dengan fungsi utama kewilayahan sebagai permukiman, pusat pemerintahan serta perdagangan dan jasa. Arahan pengembangan fasilitasnya adalah pengembangan fasilitas

\footnotetext{
${ }^{1}$ Program Pasca Sarjana Universitas Krisnadwipayana Jakarta

${ }^{2}$ Program Studi Perencanaan Wilayah dan Kota, Universitas PGRI Adi Buana Surabaya
} 
olahraga, pendidikan, pusat hiburan keluarga, mall dan fasilitas pendukung lainnya untuk skala lokal dan region. Penggunaan lahan berdasarkan BPS di wilayah penelitian pada tahun 2017 berupa permukiman $54 \%$ dan lahan non terbangun $46 \%$.

Kejadian kebakaran di Kabupaten Sidoarjo menurut data Badan Penanggulangan Bencana Daerah tahun 2017 berkisar antara 182 kejadian dengan penyebab kebakaran terbesar karena kegiatan industri dan perumahan. Kejadian kebakaran pada 5 tahun terakhir untuk kawasan perkotaan Sidoarjo yang meliputi Kecamatan Sidoarjo, Kecamatan Buduran dan Kecamatan Candi mencapai 45,4 \% kejadian dari total kejadian di seluruh Kabupaten Sidoarjo. Penyebab kebakaran yang sering terjadi di Kota Sidoarjo umumnya pada rumah penduduk dan rumput ilalang.

Terbitnya Peraturan Menteri Pekerjaan Umum No.20/PRT/M/2009 tentang Pedoman Teknis Manajemen Proteksi Kebakaran di Perkotaan, membuktikan bahwa masalah kebakaran adalah masalah yang cukup serius untuk ditanggulangi, terutama untuk pengamanan bangunan gedung dan lingkungannya. Tingkat pelayanan sarana prasarana proteksi kebakaran Kota Sidoarjo menurut PERMEN PU No.20/PRT/M/2009, minimal 3 kelurahan dilayani oleh 1 pos pemadam kebakaran. Berdasarkan ketentuan tersebut di wilayah Kota Sidoarjo yang terbagi menjadi 63 kelurahan pada tahun 2017 hanya tersedia 1 pemadam kebakaran kota skala pelayanan wilayah yang terdapat di Kelurahan Banjarkemantren Kecamatan Buduran dan 15 titik hidran. Penelitian mengenai evaluasi kesesuaian lokasi penempatan Pos PMK di Kota Surabaya Tahun 2013 menggunakan metode Nearest Neighbour Analysis (NNA), deskriptif kuantitatif, overlay dan query menunjukkan bahwa penempatan 15 PMK di Kota Surabaya sesuai persyaratan yang terdiri atas jangkauan pelayanan, ketersediaan sumur kebakaran dan dekat jalan (Purwanti \& Daryono, 2013). Penelitian mengenai pelayanan UPTD kebakaran Kota Surabaya pada Tahun 2018 menunjukkan pelayanan berdasarkan waktu tanggap 5 menit baik dan terdapat wilayah yang belum terlayani pos PMK sebanyak 29\% (Niswah, 2015). Belum diketahuinya kualitas pelayanan sarana dan prasarana proteksi kebakaran Kota Sidoarjo sesuai dengan pedoman teknis manajemen proteksi kebakaran di Indonesia menarik untuk dikaji.

Tujuan penelitian ini adalah mengevaluasi tingkat pelayanan sarana prasarana proteksi kebakaran di lingkungan permukiman perkotaan berdasarkan Pedoman Teknis Manajemen Proteksi Kebakaran di Perkotaan.

\section{METODE}

Wilayah penelitian adalah Kota Sidoarjo seluas 48.838,11 Ha yang meliputi 24 desa Kecamatan Sidoarjo, 24 desa di Kecamatan Candi dan Kecamatan Buduran 15 desa (Gambar 1). Penelitian ini menggunakan pendekatan deskriptif evaluatif. Teknik analisis yang digunakan sebaga berikut:

1. Tingkat pelayanan kelengkapan bangunan Pos PMK berdasarkan PERMEN PU (Tabel 1) Tabel 1 Standar Prasarana Pemadam Kebakaran

\begin{tabular}{|c|c|c|c|c|}
\hline No & Ruang & $\begin{array}{l}\text { Bangunan Pos Pembantu } \\
\text { Pemadam Kebakaran }\end{array}$ & $\begin{array}{l}\text { Bangunan Sektor } \\
\text { Pemadam Kebakaran }\end{array}$ & $\begin{array}{l}\text { Bangunan Wilayah } \\
\text { Pemadam } \\
\text { Kebakaran }\end{array}$ \\
\hline 1 & Luas lahan & $200 \mathrm{~m} 2$ & $400 \mathrm{~m} 2$ & $1600 \mathrm{~m} 2$ \\
\hline 2 & Ruang siaga & 2 regu (@12 orang) & 4 regu & 4 regu \\
\hline 3 & $\begin{array}{l}\text { Ruang } \\
\text { administrasi }\end{array}$ & Ada & Ada & Ada \\
\hline 4 & Ruang tunggu & Ada & Ada & Ada \\
\hline 5 & Ruang ganti & Ada & Ada & Ada \\
\hline 6 & Ruang rapat & - & Ada & Ada \\
\hline 7 & $\begin{array}{l}\text { Ruang } \\
\text { komando }\end{array}$ & - & - & Ada \\
\hline 8 & Garasi & 2 mobil pompa $4000 \mathrm{~L}$ & $\begin{array}{l}2 \text { mobil pompa } 4000 \mathrm{~L} \\
1 \text { mobil tangga } 17 \mathrm{mtr}\end{array}$ & $\begin{array}{l}2 \text { mobil } \\
4000 \mathrm{~L}\end{array}$ \\
\hline
\end{tabular}




\begin{tabular}{|c|c|c|c|c|}
\hline No & Ruang & $\begin{array}{l}\text { Bangunan Pos Pembantu } \\
\text { Pemadam Kebakaran }\end{array}$ & $\begin{array}{l}\text { Bangunan Sektor } \\
\text { Pemadam Kebakaran }\end{array}$ & $\begin{array}{l}\text { Bangunan Wilayah } \\
\text { Pemadam } \\
\text { Kebakaran }\end{array}$ \\
\hline & & & $\begin{array}{l}2 \text { mobil tangga }>30 \mathrm{mtr} \\
2 \text { mobil ambulance } \\
1 \text { mobil pemadam } \\
1 \text { mobil alat bantu } \\
\text { pernafasan } \\
2 \text { perahu karet }\end{array}$ & $\begin{array}{l}1 \text { mobil tangga } 17 \\
\text { mtr } \\
2 \text { mobil tangga }>30 \\
\text { mtr } \\
2 \text { mobil ambulance } \\
2 \text { mobil pemadam } \\
2 \text { mobil alat bantu } \\
\text { pernafasan } \\
2 \text { perahu karet }\end{array}$ \\
\hline 9 & Tandon air & $12000 \mathrm{~L}$ & $24000 \mathrm{~L}$ & $24000 \mathrm{~L}$ \\
\hline 10 & $\begin{array}{l}\text { Halaman } \\
\text { latihan }\end{array}$ & Ada & Ada & Ada \\
\hline
\end{tabular}

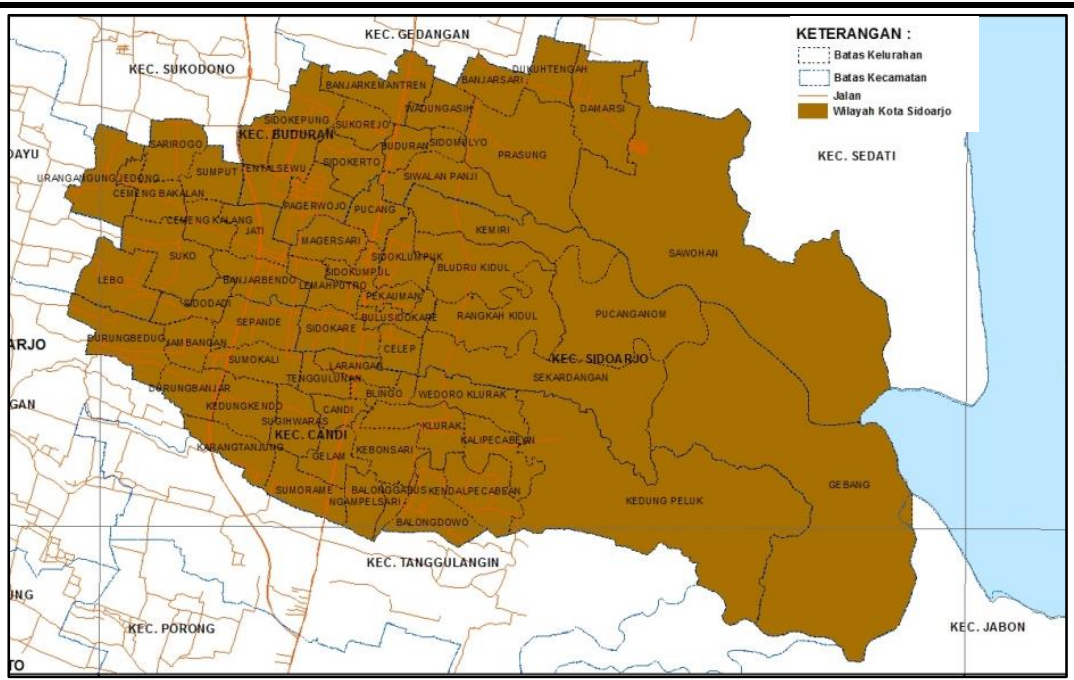

Sumber : Bappeda Kabupaten Sidoarjo, diolah 2018

\section{Gambar 1. Peta Wilayah Penelitian Kota Sidoarjo}

2. Tingkat pelayanan Pos PMK berdasarkan PERMEN PU dengan ketentuan:

a. Wilayah manajemen kebakaran ditentukan pula oleh waktu tanggap dari pos pemadam kebakaran yang terdekat. Waktu tanggap di Indonesia adalah 15 menit, terdiri dari 5 menit pertama untuk interpretasi loksi dan penyiapan sarana prasarana pemadaman, 5 menit kedua untuk perjalanan dan 5 menit ketiga untuk gelar peralatan di lokasi.

b. Daerah layanan dalam setiap WMK tidak melebihi dari radius $7,5 \mathrm{~km}$.

c. Di luar daerah tersebut dikategorikan sebagai daerah yang tidak terlindungi (unprotected area).

d. Daerah yang sudah terbangun harus mendapat perlindungan oleh mobil kebakaran yang pos terdekatnya berada dalam jarak $2,5 \mathrm{~km}$ dan berjarak $3,5 \mathrm{~km}$ dari sektor.

3. Tingkat pelayanan hidran sesuai dengan rumus pada Tabel 2. 
Tabel 2 Standart Kebutuhan Sumur Kebakaran

\begin{tabular}{|c|c|c|c|c|c|c|c|c|}
\hline No & $\begin{array}{l}\text { Klasifikasi } \\
\text { Peruntukan }\end{array}$ & $\begin{array}{l}\text { Lama } \\
\text { Pema } \\
\text { daman } \\
\text { (Jam) }\end{array}$ & $\begin{array}{l}\text { Kebutu } \\
\text { han Air } \\
/ \quad 45 \\
\text { menit } \\
\text { (liter) }\end{array}$ & $\begin{array}{l}\text { Total } \\
\text { Kebutuhan } \\
\text { Volume Air } \\
\text { Selama } \\
\text { Pemadama } \\
\text { n (liter) }\end{array}$ & $\begin{array}{l}\text { Kebu } \\
\text { tuhan } \\
\text { Sekal } \\
\mathrm{i} \\
\text { jalan } \\
/ \quad 2 \\
\text { Pos }\end{array}$ & $\begin{array}{l}\text { Total } \\
\text { Kekuranga } \\
\text { n Air }\end{array}$ & $\begin{array}{l}\text { Kapa } \\
\text { sitas } \\
\text { Su } \\
\text { mur } \\
\text { (liter) }\end{array}$ & $\begin{array}{l}\text { Kebutu } \\
\text { han } \\
\text { Sumur } \\
\text { (unit) }\end{array}$ \\
\hline A & B & C & $\mathrm{D}$ & $E=C X D$ & $\bar{F}$ & $G=E-F$ & $\mathrm{H}$ & $\begin{array}{l}\mathrm{I}= \\
\mathrm{G} / \mathrm{H}\end{array}$ \\
\hline 1 & $\begin{array}{l}\text { Permukiman } \\
\text { kepadatan } \\
\text { sedang/ren } \\
\text { dah }\end{array}$ & 4 & 12.000 & 64.000 & $\begin{array}{l}24.00 \\
0\end{array}$ & 40.000 & 4.000 & 10 \\
\hline 2 & $\begin{array}{l}\text { Permukiman } \\
\text { kepadatan } \\
\text { tinggi }\end{array}$ & 6 & 12.000 & 96.000 & $\begin{array}{l}24.00 \\
0\end{array}$ & 72.000 & 6.000 & 12 \\
\hline 3 & $\begin{array}{l}\text { Perdagangan } \\
\text { dan jasa }\end{array}$ & 10 & 12.000 & 160.000 & $\begin{array}{l}24.00 \\
0\end{array}$ & 136.000 & $\begin{array}{l}15.00 \\
0\end{array}$ & 9 \\
\hline 4 & $\begin{array}{l}\text { Industri dan } \\
\text { pergudangan }\end{array}$ & 10 & 12.000 & 160.000 & $\begin{array}{l}24.00 \\
0\end{array}$ & 136.000 & $\begin{array}{l}15.00 \\
0\end{array}$ & 9 \\
\hline
\end{tabular}

Sumber : RISPK Kota Surabaya

\section{HASIL DAN PEMBAHASAN}

Kota Sidoarjo pada Tahun 2017 tersedia 1 Pos PMK dengan skala pelayanan wilayah di Kelurahan Banjarkemantren Kecamatan Buduran dengan fasilitas bangunan Pos PMK berupa ruang siaga, ruang administrasi, ruang tunggu, ruang gantu, ruang rapat, ruang komando, garasi untuk 6 mobil pemadam, 3 buah tandon air kapasitas 5400 L dan halaman latihan (Tabel 3).

\begin{tabular}{lll}
\multicolumn{3}{l}{ Tabel } \\
N Fasilitas Bangunan Pos PMK Kelurahan Banjarkemantren \\
\hline 1 & Ruang & Bangunan Pos PMK \\
2 & Luas lahan & $1776,44 \mathrm{~m} 2$ \\
3 & Ruang siaga & $4 \mathrm{regu}$ \\
4 & Ruang administrasi & Ada \\
5 & Ruang tunggu & Ada \\
6 & Ruang ganti & Ada \\
7 & Ruang komat & Ada \\
8 & Garasi & Ada \\
9 & Tandon air & 6 mobil pemadam \\
10 & Halaman latihan & 3 tandon @ 5400 L \\
\hline
\end{tabular}

Sumber : BPBD Kabupaten Sidoarjo Tahun 2018

Berdasarkan analisis evaluatif dengan PERMEN PU pada Tabel 4 diketahui bahwa tingkat pelayanan kelengkapan bangunan Pos PMK di Kota Sidoarjo masih 56,25\%, untuk menunjang menjadi pos wilayah yang optimal maka membutuhkan penambahan beberapa prasarana pemadaman yang belum ada seperti 2 unit mobil pompa $4000 \mathrm{~L}, 1$ unit mobil tangga $17 \mathrm{~m}$ dan 1 unit mobil lebih dari $30 \mathrm{~m}$, 2unit mobil ambulance, 2 unit mobil alat bantu pernapasan, 2 unit perahu karet dan penambahan tandon air kapasitas $\pm 8.800 \mathrm{~L}$. 
Tabel 4 Tingkat Pelayanan Bangunan Pos PMK Kelurahan Banjarkemantren

\begin{tabular}{|c|c|c|c|c|c|}
\hline No & Ruang & $\begin{array}{l}\text { Bangunan Pos PMK } \\
\text { Buduran }\end{array}$ & $\begin{array}{lr}\text { PERMEN } & \text { PU } \\
\text { No.20/PRT/M/2009 }\end{array}$ & $\begin{array}{l}\text { Tingkat } \\
\text { Pelayanan (\%) }\end{array}$ & Keterangan \\
\hline 1 & Luas lahan & $1776,44 \mathrm{~m} 2$ & $1600 \mathrm{~m} 2$ & 6,25 & Terpenuhi \\
\hline 2 & Ruang siaga & 4 regu & $4 \mathrm{regu}$ & \multirow{2}{*}{$\begin{array}{l}6,25 \\
6,25\end{array}$} & Terpenuhi \\
\hline 3 & $\begin{array}{l}\text { Ruang } \\
\text { administrasi }\end{array}$ & Ada & Ada & & Terpenuhi \\
\hline 4 & Ruang tunggu & Ada & Ada & 6,25 & Terpenuhi \\
\hline 5 & Ruang ganti & Ada & Ada & 6,25 & Terpenuhi \\
\hline 6 & Ruang rapat & Ada & Ada & 6,25 & Terpenuhi \\
\hline \multirow[t]{4}{*}{7} & $\begin{array}{l}\text { Ruang } \\
\text { komando }\end{array}$ & Ada & Ada & 6,25 & Terpenuhi \\
\hline & & $\begin{array}{l}\text { mobil pompa } 4000 \mathrm{~L} \\
\text { (tidak ada) }\end{array}$ & $\begin{array}{l}2 \text { mobil pompa } \\
4000 \mathrm{~L}\end{array}$ & 0 & Tidak Terpenuhi \\
\hline & & $\begin{array}{l}\text { mobil tangga } 17 \mathrm{mtr} \\
\text { (tidak ada) }\end{array}$ & $\begin{array}{l}1 \text { mobil tangga } 17 \\
\mathrm{mtr}\end{array}$ & 0 & Tidak Terpenuhi \\
\hline & & $\begin{array}{l}\text { mobil tangga }>30 \\
\text { mtr } \\
\text { (tidak ada) }\end{array}$ & $\begin{array}{l}2 \text { mobil tangga }>30 \\
\mathrm{mtr}\end{array}$ & 0 & Tidak Terpenuhi \\
\hline \multirow[t]{4}{*}{8} & Garasi & $\begin{array}{l}\text { mobil ambulance } \\
\text { (tidak ada) }\end{array}$ & 2 mobil ambulance & 0 & Tidak Terpenuhi \\
\hline & & 6 mobil pemadam & 2 mobil pemadam & 6,25 & Terpenuhi \\
\hline & & $\begin{array}{l}\text { mobil alat bantu } \\
\text { pernafasan } \\
\text { (tidak ada) }\end{array}$ & $\begin{array}{l}2 \text { mobil alat bantu } \\
\text { pernafasan }\end{array}$ & 0 & Tidak Terpenuhi \\
\hline & & $\begin{array}{l}\text { perahu karet } \\
\text { (tidak ada) }\end{array}$ & 2 perahu karet & 0 & Tidak Terpenuhi \\
\hline 9 & Tandon air & $\begin{array}{l}3 \text { tandon @ } 9400 \mathrm{~L} \\
=16200 \mathrm{~L}(-8800 \mathrm{~L})\end{array}$ & $24000 \mathrm{~L}$ & 0 & Tidak Terpenuhi \\
\hline 10 & $\begin{array}{l}\text { Halaman } \\
\text { latihan } \\
\quad \text { Rata-rata }\end{array}$ & Ada & Ada & 56,25 & Terpenuhi \\
\hline
\end{tabular}

Sumber : Hasil Analisis, 2018

\section{Tingkat Pelayanan Pos PMK dan Hidran}

Sebaran sumur bor atau hidran di wilayah Kota Sidoarjo di Tahun 2017 berdasarkan data BPBD berjumlah 15 buah dengan lokasi persebarannya di Jalan Trunojoyo, Jalan Pahlawan, Jalan Mojopahit, Jalan Perum Pondok Jati, Jalan Tamrin, Jalan Raden Patah, Jalan Samanhudi, dan Jalan Cipto Mangukusumo seperti pada Tabel 4. Kondisi hidran atau sumur yang tersebar di wilayah Kota Sidoarjo masih baik dan baru. Kondisinya masih dapat dimaksimalkan dalam membantu pemadaman kebakaran.

Kota Sidoarjo tersedia 1 Pos PMK skala Wilayah di Kelurahan Banjarkemantren Kecamatan Buduran melayani 63 kelurahan dengan tingkat pelayanannya hanya 33,33\%. Tingkat pelayanan ideal menurut PERMEN PU adalah 1 Pos PMK melayani maksimal 3 kelurahan. Pos pemadam yang ideal jika dekat dengan jalan utama. Jalan dikatakan dekat apabila jarak antara jalan dengan pos pemadam $<75$ meter, sedangkan jalan dikatakan sedang apabila jarak antara jalan dengan pos pemadam 76-150 meter, dan dikatakan jauh apabila jarak antara jalan dengan pos pemadam > 150 meter (Purwanti \& Daryono, 2013).

Berdasarkan data BPBD Tahun 2017, wilayah Kota Sidoarjo tersedia 15 unit hidran yang tersebar di wilayah Kecamatan Sidoarjo. Tingkat pelayanan hidran Kota Sidoarjo (Tabel 5) pada Tahun 2018 dibandingkan dengan kebutuhan sebesar 27,78\%. Penelitian Handayani (2016) menunjukkan bahwa pemenuhan hidran di beberapa perumahan di Kabupaten Sidoarjo sebesar 55\% (Handayani \& HS, 2016). Hasil analisis senada dengan Sumasita (2015), hidran kebakaran 
sebaiknya diletakkan pada lokasi yang strategis dan daerah yang memiliki kepadatan tinggi atau di pusat-pusat kota yang menjadi pusat keramaian atau kegiatan. Lokasi hidran juga harus dekat dengan jalan besar, atau persimpangan agar lebih mudah dicapai (Sumasita, Rezagama, \& Handayani, 2015).

Rata-rata tingkat pelayanan sarana proteksi kebakaran di wilayah Kota Sidoarjo pada Tahun 2018 sebesar 31,9\%, sehingga masih perlu penambahan 2 Pos PMK pembantu, 1 Pos PMK Sektor dan hidran 39 unit. Analisis lokasi dan jumlah stasiun pemadam kebakaran juga pernah dilakukan di Kota Yogyakarta berdasarkan Keputusan Menteri Negara Pekerjaan Umum No. 11/KPTS/2000 yang menyimpulkan bahwa perlu penambahan Pos PMK, penambahan WMK dan peningkatan kapasitas SDM (Nurokhman, 2016) (Sutaryo \& Suryadi, 2019) (H, Widayanti, Kurniawan, Yuniarma, \& Lestari, 2018) dan (Akbar, Iriana, \& Djuniati, 2014). Hasil analisis ini belum sesuai dengan Rusli, ketersediaan sarana dan prasarana proteksi kebakaran dapat mempengaruhi tingkat keberhasilan pencegahan dan penanggulangan kebakaran (Rusli, 2011).

Tabel 5 Tingkat Pelayanan Sarana Proteksi Kebakaran Tahun 2018

\begin{tabular}{lllll}
\hline No & $\begin{array}{l}\text { Ketersediaan } \\
\text { Sarana }\end{array}$ & $\begin{array}{c}\text { Eksisting } \\
\text { (unit) }\end{array}$ & $\begin{array}{l}\text { Kebutuhan } \\
\text { PERMEN PU } \\
\text { (unit) }\end{array}$ & $\begin{array}{l}\text { Menurut } \\
\text { Pelayanan (\%) }\end{array}$ \\
\hline 1 & Pos Pembantu & 0 & 2 & 0 \\
2 & Pos Sektor & 0 & 1 & 0 \\
3 & Pos Wilayah & 1 & 1 & 100 \\
& Rata-rata & & & 33,33 \\
4 & Hidran & 15 & 54 & 27,78 \\
& Rata-rata & & & 31,9 \\
\hline
\end{tabular}

Sumber : Hasil Analisis, 2018

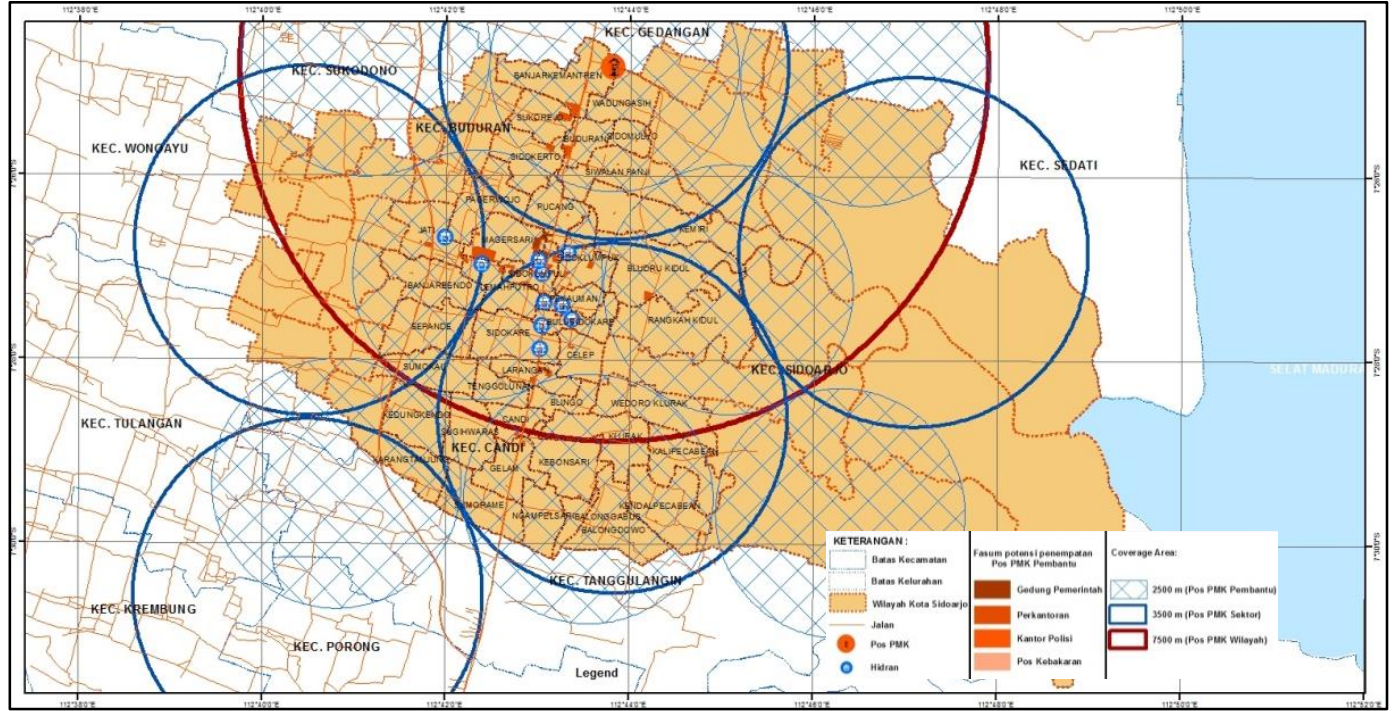

Sumber : Hasil Analisis, 2018

Gambar 2. Peta Analisis Tingkat Pelayanan Pos PMK Kota Sidoarjo Tahun 2018 


\section{Tingkat Pelayanan Kelembagaan}

Organisasi lembaga yang menangani kebakaran di Kabupaten Sidoarjo adalah Sub Bidang Kebakaran yang termasuk dalam kesatuan BPBD Kabupaten Sidoarjo. Sebelum menjadi bagian dari bidang di BPBD Kabupaten Sidoarjo, Bidang Kebakaran menjadi bagaian Dinas PU Cipta Karya. Jumlah personil pemadam kebakaran Kabupaten Sidoarjo sampai Tahun 2018 dapat dirinci sebagai berikut (Tabel 6):

1. Personil dengan status PNS mencapai 40 orang.

2. Personil yang masih berstatus CPNS 19 orang.

3. Personil dengan status honorer daerah sebanyak 5 orang.

Tabel 6. Tingkat Kelembagaan PMK di Kabupaten Sidoarjo Tahun 2018

\begin{tabular}{|c|c|c|c|c|c|c|c|c|}
\hline \multirow{2}{*}{ Jabatan } & \multicolumn{3}{|c|}{ Status Kepegawaian } & \multicolumn{5}{|c|}{ Pendidikan } \\
\hline & PNS & CPNS & HONOR & S2 & S1 & SMU & SMP & SD \\
\hline \multicolumn{9}{|l|}{ Pejabat Struktural } \\
\hline 1. Kepala Bidang & 1 & - & - & 1 & - & - & & \\
\hline 2. Kasi Pencegahan dan Pengendalian & 1 & - & - & & 1 & - & - & \\
\hline 3. Kasi Sarana- Prasarana & 1 & - & - & - & - & - & - & \\
\hline 4. Kasi Operasional & - & - & - & - & - & 1 & - & \\
\hline \multicolumn{9}{|l|}{ Staf Seksi Pencegahan } \\
\hline 1. Tim Pemeriksa \& Pengujian APK & 4 & 2 & 3 & - & 1 & 6 & 2 & \\
\hline 2. Sek. Tim Pemeriksa \& Pengujian APK & - & - & 1 & - & - & 1 & - & \\
\hline \multicolumn{9}{|l|}{ Staf Seksi Pencegahan Sarana-Prasarana } \\
\hline 1. BPP & 1 & - & - & - & 1 & - & - & - \\
\hline 2. Mekanik & 1 & - & - & - & - & - & - & 1 \\
\hline 3. Administrasi & - & 1 & - & - & - & 1 & - & - \\
\hline \multicolumn{9}{|l|}{ Staf Seksi Operasional } \\
\hline 1. Komandan Pleton & 2 & - & - & - & - & 2 & - & - \\
\hline 2. Komadan Regu & 8 & - & - & - & - & 7 & 1 & - \\
\hline 3. Sopir & 8 & 2 & & - & - & 7 & 1 & - \\
\hline 4. Anggota & 11 & 14 & 1 & - & - & 22 & 3 & - \\
\hline 5. Administrasi & 2 & - & - & - & - & 2 & - & - \\
\hline Jumlah & 40 & 19 & 5 & 1 & 3 & 49 & 7 & 4 \\
\hline
\end{tabular}

Sumber: BPBD, 2018

Tabel 7 menunjukkan bahwa tingkat pelayanan personil Pos PMK Wilayah Kota Sidoarjo kesesuaian dengan PERMEN PU sebesar 33,33\%, karena personil Pos PMK eksisting belum spesifik pembagian berdasarkan keahliannya. Analisis tim pemadam kebaran juga bisa menggunakan Permen PU No. 25/PRT/M/2008, Permendagri No. 16 Tahun 2009, NFPA 1001 dan NFPA 1500 (Widayanto, 2016).

Hasil kajian sebelumnya menyebutkan bahwa kebutuhan masyarakat akan armada atau personil kebakaran merupakan faktor yang mempengaruhi partisipasi masyarakat dalam menghadapi risiko kebakaran permukiman (Lestari, Pramono, \& Nefianto, 2017). Senada dengan Nawawi, masyarakat perlu diikutkan dalam kegiatan penyuluhan kebakaran oleh instruktur dari PMK yang telah tersertifikasi (Nawawi, 2017). Tingkat pelayanan pada Dinas Kebakaran juga dapat diukur menggunakan aspek kemudahan, aspek kecepatan, aspek ketepatan, dan aspek keamanan (Veranita \& Maolani, 2018).

Peran serta masyarakat Kota Sidoarjo (Tabel 8) dalam proteksi kebakaran jika dibandingkan PERMEN PU No. 20/PRT/M/2009 masih sangat rendah (0\%), karena adanya anggapan bahwa kegiatan ini tugas pemerintah daerah. Faktor masyarakat serta peringatan dini merupakan faktor yang sangat penting dan potensial dalam upaya mitigasi bahaya kebakaran (Sagala, Aditama, \& Sianturi, 2013). Tingkat masyarakat perlu dibentuk komunitas tanggap bencana kebakaran dibawah koordinasi pemerintah daerah (Nurokhman, 2016). 
Tabel 7 Analisa Tingkat Pelayanan Personil Pos PMK Wilayah

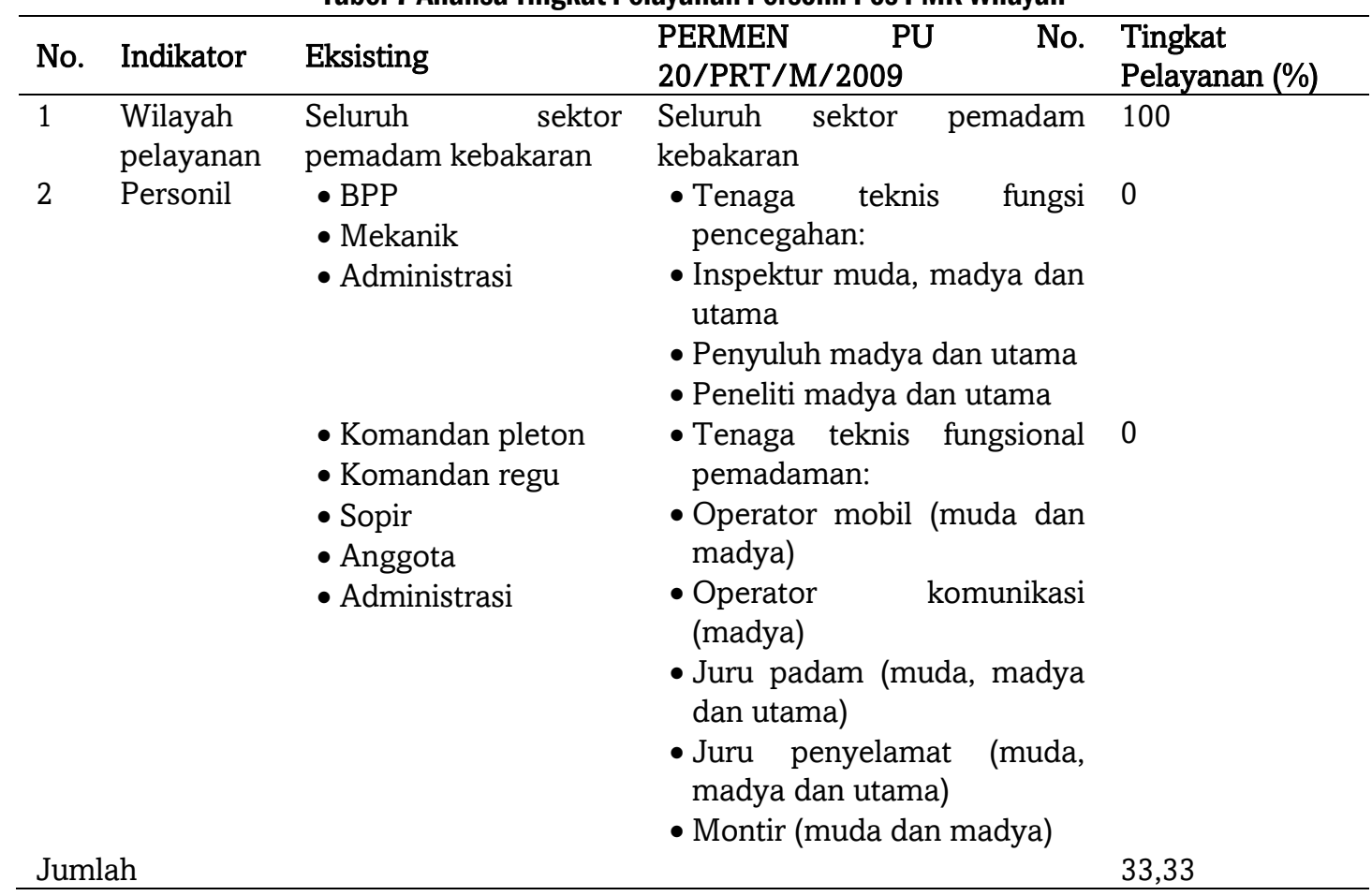

Sumber : Hasil Analisa,2018

Tabel 8 Analisa Tingkat Pelayanan Peran Serta Masyarakat

\begin{tabular}{|c|c|c|c|c|}
\hline No & Indikator & Kondisi Eksisting & $\begin{array}{ll}\text { PERMEN PU } & \text { No. } \\
20 / \mathrm{PRT} / \mathrm{M} / 2009 & \\
\end{array}$ & $\begin{array}{l}\text { Tingkat } \\
\text { Pelayanan \%) }\end{array}$ \\
\hline 1 & Satlakar & Masih insidental & $\begin{array}{l}\text { Tersedia organisasi SATLAKAR } \\
\text { pada tingkat RW }\end{array}$ & 0 \\
\hline 2 & $\begin{array}{l}\text { Forum (Dewan) } \\
\text { Keselamatan } \\
\text { Kebakaran }\end{array}$ & Belum Ada & $\begin{array}{l}\text { Tersedia Forum Komunikasi } \\
\text { Keselamatan Kebakaran Tingkat } \\
\text { Kecamatan dan Kota/Propinsi }\end{array}$ & 0 \\
\hline 3 & $\begin{array}{l}\text { Fasilitas } \\
\text { SATLAKAR }\end{array}$ & Belum Ada & $\begin{array}{l}\text { Fasilitas SATLAKAR: } \\
\text { Sarana, prasarana, diklat kepala, } \\
\text { diklat anggota, latihan } \\
\text { pemadaman, SOP }\end{array}$ & 0 \\
\hline \multicolumn{2}{|c|}{ Jumlah } & & & 0 \\
\hline
\end{tabular}

Sumber : Hasil Analisa, 2018

\section{KESIMPULAN}

Berdasarkan hasil analisis evaluatif dengan PERMEN PU No. 20/2009 maka dapat disimpulkan bahwa tingkat pelayanan kelengkapan bangunan Pos PMK, tingkat pelayanan Pos PMK, hidran dan kelembagaan proteksi kebakaran di Kota Sidoarjo masih dibawah standar (48\%). Tingkat pelayanan terbesar dari kelengkapan bangunan Pos PMK yaitu 56,25\%, sedangkan terendah adalah tingkat partisipasi masyarakat dalam proteksi kebakaran yaitu $0 \%$. Pelayanan sarana dan prasarana proteksi kebakaran permukiman perkotaan Kota Sidoarjo memerlukan penambahan fasilitas bangunan Pos PMK di Kelurahan Banjarkemantren, penambahan Pos PMK, penambahan hidran dan pembentukan Satlakar proteksi kebakaran.

\section{DAFTAR PUSTAKA}

Akbar, H., Iriana, R. T. K., \& Djuniati, S. (2014). Optimasi Lokasi dan Stasiun Pemadam Kebakaran di Kota Bangkinang. Jurnal Online Mahasiswa Fakultas Teknik Universitas Riau, 1(2), 1-11. Retrieved from https://www.neliti.com/publications/205987/optimasi-lokasi-dan-stasiun-pemadan-kebakaran-di-kotabangkinang 
Andriyanto, H. (2013). Pemetaan potensi dan resiko kebakaran di kota surakarta. Universitas Sebelas Maret Surakarta. Retrieved from http://digilib.uns.ac.id

H, F. P., Widayanti, B. H., Kurniawan, A., Yuniarma, A., \& Lestari, A. P. (2018). Kajian Lokasi Pos Induk Pemadam Kebakaran terhadap Bencana Kebakaran di Kota Mataram. Jurnal Planoearth, 3(2), 63-66. Retrieved from https://www.researchgate.net/publication/330560744_KAJIAN_LOKASI_POS_INDUK_PEMADAM_KEB AKARAN_TERHADAP_BENCANA_KEBAKARAN_DI_KOTA_MATARAM

Handayani, K. D., \& HS, M. S. (2016). Tingkat Kesesuaian Prasarana Jaringan dan Lingkungan Perumahan di Kabupaten Sidoarjo dan Kota Surabaya. Jurnal Teknik Waktu, 14(1), 15-22. Retrieved from http://jurnal.unipasby.ac.id/index.php/waktu/article/view/03

Lestari, D. P., Pramono, R., \& Nefianto, T. (2017). Analisis Partisipasi Masyarakat Melalui barisan Pemadam Kebakaran Swadaya Dalam Menghadapi Risiko Kebakaran Permukiman di Kota Banjarmasin. Jurnal Manajemen Kebakaran, 3(2), 23-47.

Nawawi, A. (2017). Kualitas Pelayanan Pada Unit Pelaksana Kabupaten Purwakarta. Jurnal JIA Fakultas Ilmu Administrasi (FIA) UNSUB, 20, 71-89.

Niswah, K. (2015). Pengaruh Kondisi Sosial Ekonomi Masyarakat Terhadap Kualitas Fisik Bangunan Permukiman di Kecamatan Gubug Kabupaten Grobogan. Universitas Negeri Semarang. Retrieved from https://lib.unnes.ac.id/21835/

Nurokhman. (2016). Studi ketersediaan infrastruktur proteksi pemadam kebakaran dan kelembagaannya di kota yogyakarta. Jurnal Teknik Sipil UCY, XI(1), 35-49. Retrieved from https://jurnal.ucy.ac.id/index.php/teknik_sipil/article/view/243/257

Purwanti, E., \& Daryono. (2013). Evaluasi Terhadap Lokasi Penempatan Pos Pemadam Kebakaran di Wilayah Kota Surabaya. Swara Bhumi E-Journal, 2.

Rusli. (2011). Faktor-Faktor Penentu Dalam Analisis Sistem Proteksi Kebakaran Dalam Suatu Kawasan (Studi kasus: Kota Parigi). Jurnal Smartek, 9(3), 196-211.

Sagala, S., Aditama, P., \& Sianturi, D. G. (2013). Analisis Upaya Pencegahan Bencana Kebakaran di Permukiman Padat Perkotaan Kota Bandung, Studi Kasus Kelurahan Sukahaji. Resilient Development Initiative, (3).

Sumasita, K. J., Rezagama, A., \& Handayani, D. S. (2015). Perancangan Letak Hidran Kebakaran Pada Jaringan Distribusi Penyediaan Air Minum Studi Kasusus Kecamatan Sayung Kabupaten Denak. Jurnal Teknik Lingkungan, 4.

Sutaryo, \& Suryadi, D. (2019). Analisis Sebaran Lokasi Pos Pemadam Kebakaran di Kecamatan Gambir Jakarta Pusat. Jurnal Ilmiah Plano Krisna, 13(1), 1-13.

Veranita, M., \& Maolani, D. Y. (2018). Analisis Kualitas Pelayanan Publik Pada Dinas Pencegahan dan Penanggulangan Kebakaran Kota Bandung. Jurnal Ilmu Sosial Dan Ilmu Politik, 8(2), 277-290. Retrieved from https://journal.uinsgd.ac.id/index.php/jispo/article/view/3957

Widayanto, P. (2016). Analisis Kinerja Tim Pemadam Kebakaran Dalam Upaya Penanggulangan Kejadian Kebakaran Di Dinas Kebakaran Kota Semarang. Universitas Negeri Semarang. 